\title{
KORELASI KONSENTRASI IAA DAN BAP TERHADAP PERTUMBUHAN KULTUR JARINGAN SENGON (Paraserianthes falcataria)
}

\author{
(Correlation of IAA and BAP Concentration to the Growth of Sengon Tissue Culture)
}

\author{
Stefani Eka Nurhanis, Reine Suci Wulandari, Rosa Suryantini \\ Fakultas Kehutanan Universitas Tanjungpura, Jalan Daya Nasional Pontianak, 78124 \\ E-mail: stefaniekanurhanis16@gmail.com
}

\begin{abstract}
Sengon (Paraserianthes falcataria) is a fast growing plant that has high economic value. But the presence of sengon in the wild every year begins to decline due to the high demand for sengon wood. To increase the availability of sengon seeds, the propagation is carried out through tissue culture techniques. This study aims to determine the correlation between growth regulators (IAA and BAP) and the growth of sengon explants. This study used an experimental method with treatment of IAA concentrations of $0 \mathrm{mg} / \mathrm{L}, 0,5 \mathrm{mg} / \mathrm{L}, 1 \mathrm{mg} / \mathrm{L}, 1,5$ $\mathrm{mg} / \mathrm{L}$, and $2 \mathrm{mg} / \mathrm{L}$ and BAP concentrations of $0 \mathrm{mg} / \mathrm{L}, 1 \mathrm{mg} / \mathrm{L}, 2 \mathrm{mg} / \mathrm{L}, 3 \mathrm{mg} / \mathrm{L}$ and $4 \mathrm{mg} / \mathrm{L}$. Each treatment was repeated three times and analyzed using a simple correlation test analysis. The results showed, that the higher concentration of IAA and BAP, causes decreased growth of sengon explants, so the concentration of IAA and BAP gives a negative correlation, but provides a strong relationship to the percentage days of appearance of roots, shoots and leaves, plantlet height, root length, and number of leaves.
\end{abstract}

Keywords : Correlation, plant tissue isolation method, sengon.

\section{PENDAHULUAN}

Sengon (Paraserianthes falcataria) merupakan tanaman fast growing, yaitu jenis tanaman yang memiliki pertumbuhan relatif cepat, masa panen yang pendek, produktivitas tinggi, dan memberikan dampak yang baik sebagai tanaman produksi maupun tanaman konservasi (Damaris 2012). Sengon, seperti halnya jenis-jenis pohon cepat tumbuh lainnya, diharapkan menjadi jenis yang semakin penting bagi industri perkayuan dimasa mendatang, terutama ketika persediaan kayu pertukangan dari hutan alam semakin berkurang. Hasil pengumpulan Data Kehutanan pada BPS 2015 menunjukkan bahwa jumlah produksi kayu sengon sebesar 2,58 juta $\mathrm{m}^{3}(5,86 \%)$. Produksi kayu sengon itu sendiri mengalami penurunan pada triwulan II, III, dan IV, produksinya menurun menjadi 0,70 juta $\mathrm{m}^{3}, 0,62$ juta $\mathrm{m}^{3}$ dan 0,56 juta $\mathrm{m}^{3}$. Salah satu usaha untuk lebih meningkatkan produksi pohon sengon dengan kualitas yang unggul dapat dilakukan dengan cara kultur jaringan.

Kultur jaringan merupakan metode untuk mengisolasi bagian tanaman seperti sel, jaringan atau organ, serta membudidayakannya dalam lingkungan yang aseptik (Sulistiani dan Samsul 2015). Keberhasilan perbanyakan tanaman dengan metode kultur jaringan secara umum sangat tergantung pada sumber eksplan dan jenis media. Sumber eksplan pada 
kultur jaringan merupakan bagian dari tanaman yang masih aktif membelah (jaringan meristem), macam-macam eksplan yang dapat digunakan yaitu pucuk, daun, akar, biji, tunas, kotiledon, hipokotil, buah, dan bakal buah (Henuhili 2013). Media tumbuh pada kultur jaringan sangat besar pengaruhnya terhadap pertumbuhan dan perkembangan eksplan serta bibit yang dihasilkannya. Komposisi media yang digunakan tergantung dengan jenis tanaman yang akan diperbanyak. Media yang digunakan biasanya terdiri dari agar-agar, garam mineral, vitamin, dan zat pengatur tumbuh.

Zat Pengatur Tumbuh (ZPT) yang biasa digunakan dalam media kultur jaringan yaitu auksin dan sitokinin. Auksin merupakan ZPT yang berperan dalam menginduksi perakaran pada perbanyakan secara in vitro, sedangkan sitokinin berperan dalam induksi tunas eksplan. Penelitian Siska et al. (2013), diketahui bahwa tunas dari tanaman anggrek yang paling cepat muncul yaitu dengan konsentrasi IAA $0 \mathrm{mg} / \mathrm{L}$ dan BAP $3 \mathrm{mg} / \mathrm{L}$, sedangkan pada konsentrasi IAA $1,5 \mathrm{mg} / \mathrm{L}$ dan BAP 1 $\mathrm{mg} / \mathrm{L}$ menghasilkan jumlah tunas terbanyak. Menurut Herawan et al. (2015), perlakuan $20 \mathrm{mg} / \mathrm{L}$ IBA dan 1 mg/L IAA memberikan respon paling baik terhadap pertumbuhan akar cendana (Santalum album L.). Tanaman sengon sendiri belum diketahui konsentrasi ZPT yang memiliki korelasi terhadap pertumbuhannya, terutama untuk penggunaan ZPT auksin golongan IAA dan sitokinin golongan BAP. Oleh karena itu, perlu dilakukan penelitian untuk mendapatkan korelasi konsentrasi IAA dan BAP terbaik terhadap pertumbuhan eksplan sengon. Tujuan penelitian ini adalah untuk menentukan korelasi antara ZPT IAA dan BAP terhadap pertumbuhan eksplan sengon. Manfaat hasil penelitian ini yaitu dapat mempermudah penyediaan bibit sengon yang berkualitas secara reproduksi vegetatif dengan teknik kultur jaringan.

\section{METODE PENELITIAN}

Penelitian ini dilaksanakan di Laboratorium Silvikultur Fakultas Kehutanan, Universitas Tanjungpura, dengan waktu penelitian selama 6 bulan. Alat yang digunakan adalah erlenmeyer, laminar air flow cabinet, gelas ukur, gelas piala, hot plate, botol kultur, autoclave, $\mathrm{pH}$ meter, pinset, sendok pengaduk, hand sprayer, timbangan analitik, gelas arloji, bunsen, dan jangka sorong. Bahan yang digunakan dalam penelitian ini adalah bahan-bahan media MS (hara makro, mikro, zat besi, gula, myo-inositol dan vitamin), biji sengon, larutan IAA, larutan BAP, alkohol, bubuk agar-agar, aquades, alumunium foil, kertas saring, spiritus, kertas label, deterjen cair, dan chlorox.

Penelitian ini dimulai dengan melakukan sterilisasi ruang kerja, sterilisasi alat, pembuatan media tanam, sterilisasi media tanam, dan persiapan bahan tanam. Variabel yang diamati dalam penelitian ini adalah hari 
munculnya akar, tunas dan daun, tinggi planlet, panjang akar, serta jumlah daun. Metode yang digunakan adalah metode eksperimen dengan menggunakan perlakuan konsentrasi IAA sebesar $0 \mathrm{mg} / \mathrm{L}, 0,5 \mathrm{mg} / \mathrm{L}, 1$ $\mathrm{mg} / \mathrm{L}, 1,5 \mathrm{mg} / \mathrm{L}$, serta $2 \mathrm{mg} / \mathrm{L}$ dan konsentrasi BAP sebesar $0 \mathrm{mg} / \mathrm{L}, 1$ $\mathrm{mg} / \mathrm{L}, 2 \mathrm{mg} / \mathrm{L}, 3 \mathrm{mg} / \mathrm{L}$ dan $4 \mathrm{mg} / \mathrm{L}$. Setiap perlakuan diulang sebanyak 3 kali ulangan dan dianalisis dengan

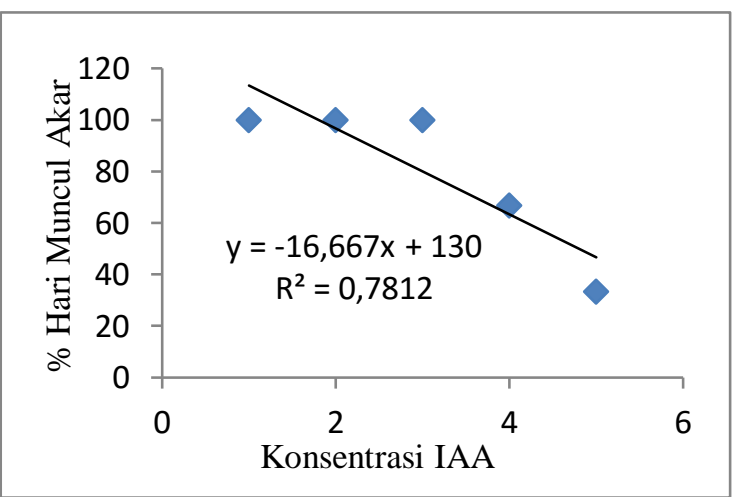

Gambar 1. Korelasi IAA Terhadap Persen Hari Munculnya Akar pada BAP $0 \quad \mathrm{mg} / \mathrm{L} \quad$ (Correlation between IAA Concentration with the Percentage of Days the Appearance Roots in the 0 mg/L of BAP Concentration)

Gambar 1 dan 2 menunjukkan bahwa konsentrasi IAA dan BAP memberikan korelasi yang negatif terhadap persentase hari munculnya akar. Konsentrasi IAA memiliki hubungan yang kuat terhadap persentase hari munculnya akar, sedangkan konsentrasi BAP memiliki hubungan yang lemah terhadap persentase hari munculnya akar, dapat dilihat dari besarnya koefisien korelasi sebesar $78 \%$ dan $9 \%$. menggunakan analisis uji korelasi sederhana.

\section{HASIL DAN PEMBAHASAN}

\section{A. Persentase Hari Munculnya Akar}

Kemunculan akar merupakan proses awal dari pertumbuhan eksplan sengon serta merupakan faktor penting dalam perbanyakan menggunakan metode kultur jaringan. Berikut merupakan korelasi konsentrasi IAA dan BAP terhadap persen hari munculnya akar.

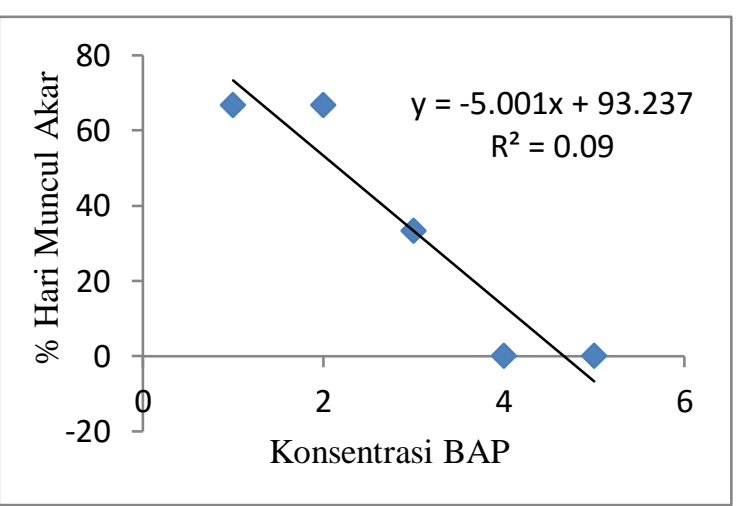

Gambar 2. Korelasi BAP Terhadap Persen Hari Munculnya Akar pada IAA $1,5 \mathrm{mg} / \mathrm{L}$ (Correlation between BAP Concentration with the Percentage of Days the Appearance Roots in the 1,5 $m g / L$ of IAA Concentration)

Kemunculan akar sangat tergantung pada konsentrasi IAA yang diberikan. Akar adalah organ tanaman yang berfungsi untuk menyerap nutrisi (unsur hara) baik makro maupun mikro dari media tumbuh untuk kemudian digunakan dalam proses tumbuh dan berkembangnya tanaman. Gambar 1 menunjukkan bahwa hanya dengan memberikan ZPT IAA dapat memacu pertumbuhan akar secara lebih cepat. Hal ini sesuai dengan pendapat 
Pucchooa dan Sookum (2000) yang mengatakan bahwa pengakaran eksplan pada kultur in vitro didapat dari medium tanpa penambahan BAP. Analisis korelasi menunjukkan bahwa pada pemberian $0 \mathrm{mg} / \mathrm{L}$ dan $1 \mathrm{mg} / \mathrm{L}$ BAP memberikan pengaruh yang sangat kuat terhadap kemunculan akar, tetapi ketika konsentrasi BAP yang diberikan lebih tinggi maka akan menghambat proses kemunculan akar. Hal ini sesuai dengan pendapat Santoso dan Nursandi (2004) bahwa dalam kultur jaringan, penambahan sitokinin dapat menghambat pembentukan akar. Gambar 2 juga menunjukkan bahwa pengaruh BAP terhadap kemunculan akar sangat lemah, dibuktikan dengan besarnya koefisien determinasi hanya sebesar $9 \%$.

\section{B. Panjang Akar}

Pertumbuhan panjang akar sangat dipengaruhi oleh konsentrasi IAA yang diberikan. Koefisien determinasi konsentrasi IAA terhadap panjang akar pada konsentrasi BAP $1 \mathrm{mg} / \mathrm{L}$ sebesar 96\% (Gambar 3). Koefisien determinasi konsentrasi BAP terhadap panjang akar pada konsentrasi IAA 0 mg/L sebesar 89\% (Gambar 4). Hasil tersebut dapat disimpulkan bahwa hubungan antara konsentrasi IAA terhadap panjang akar sangat kuat. Menurut Rukmana (2009), zat pengatur tumbuh auksin merangsang pertumbuhan yang sangat berpengaruh dalam pembentukan akar-akar dan panjang akar, sehingga menyebabkan tanaman dapat menyerap air beserta unsur hara yang lebih banyak untuk pertumbuhan tanaman. Pemberian ZPT dalam jumlah kecil mampu memacu proses pertumbuhan panjang akar karena dalam tubuh eksplan terdapat hormon endogen yang dapat memacu proses pertumbuhan meskipun konsentrasi ZPT yang diberikan sedikit.Hal ini sesuai dengan pendapat Gunawan (2008), yang mengemukakan bahwa zat pengatur tumbuh endogen merupakan faktor untuk memacu proses tumbuh dan morfogenesis eksplan, baik membentuk kalus, akar, tunas dan planlet.

$\begin{array}{ccr}\text { Rahardja } & \text { (2007), } & \text { juga } \\ \text { mengemukakan } & \text { bahwa } & \text { respon }\end{array}$ pertumbuhan eksplan yang dikultur tergantung pada interaksi serta keseimbangan antara zat pengatur tumbuh endogen yang ada pada eksplan dan zat pengatur tumbuh eksogenyang ditambahkan dalam media. Menurut Agustina (2002), munculnya akar disebabkan oleh masih tingginya auksin yang terdapat dalam eksplan (endogen) sehingga walaupun ditambahkan auksin secara eksogen dengan konsentrasi rendah akan dapat membentuk akar. Pembentukan akar juga tidak terlepas dari prosespembelahan jaringan yang aktif dan berdiferensiasi, dan ditunjang oleh adanya senyawa organik dan anorganik yang terdapat dalam media sederhana. 


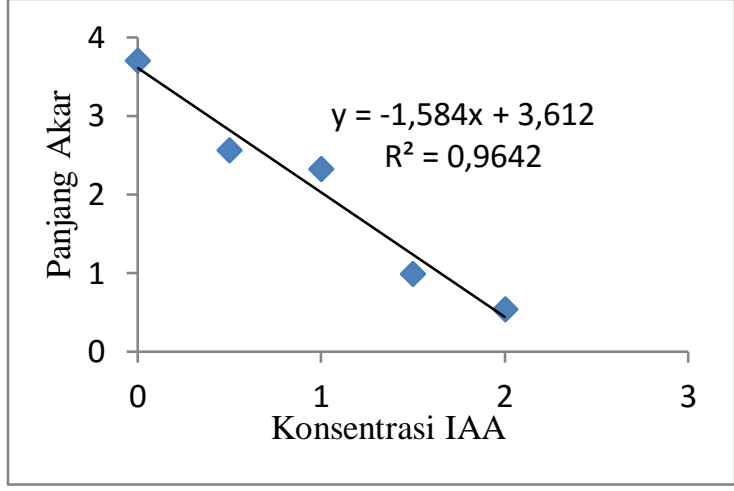

Gambar 3. Korelasi IAA Terhadap Panjang Akar pada BAP 1 $\mathrm{mg} / \mathrm{L}$ (Correlation between IAA Concentration with the Roots Lenght in the $1 \mathrm{mg} / \mathrm{L}$ of BAP Concentration)

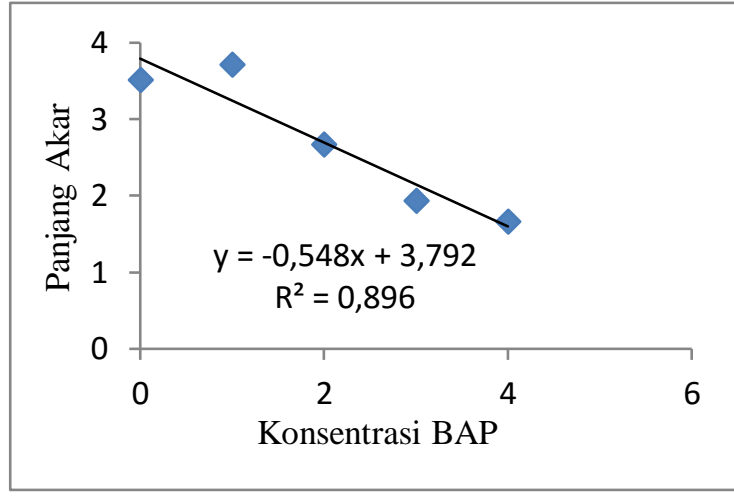

Gambar 4. Korelasi BAP Terhadap Panjang Akar pada IAA 0 $\mathrm{mg} / \mathrm{L}$ (Correlation between $B A P$ Concentration with the Roots Lenght in the $0 \mathrm{mg} / \mathrm{L}$ of IAA Concentration)

\section{Persentase Hari Munculnya Tunas}

Kemunculan tunas merupakan proses awal dari pertumbuhan eksplan sengon. Korelasi konsentrasi IAA dan BAP terhadap persentase hari munculnya tunas tersaji pada Gambar 5 dan 6.

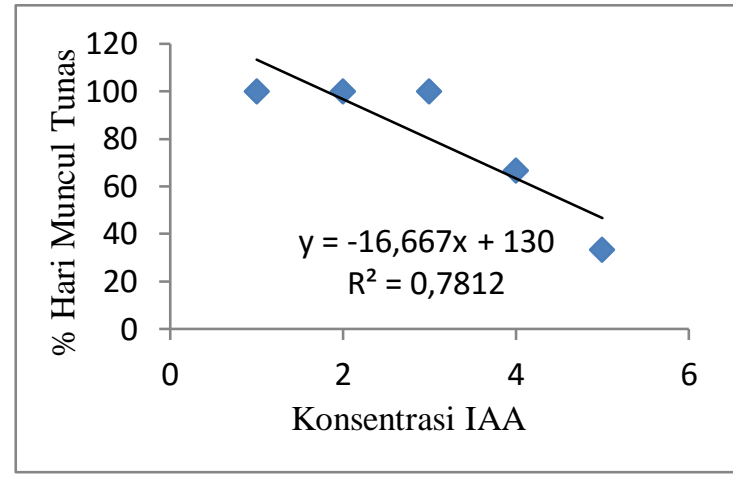

Gambar 5. Korelasi IAA Terhadap Persen Hari Munculnya Tunas pada BAP $0 \mathrm{mg} / \mathrm{L}$ (Correlation between IAA Concentration with the Percentage of Shoots in the $0 \quad m g / L$ of $B A P$

Gambar 5 dan 6 menunjukkan bahwa pemberian IAA terhadap munculnya tunas eksplan sengon memiliki hubungan yang lemah

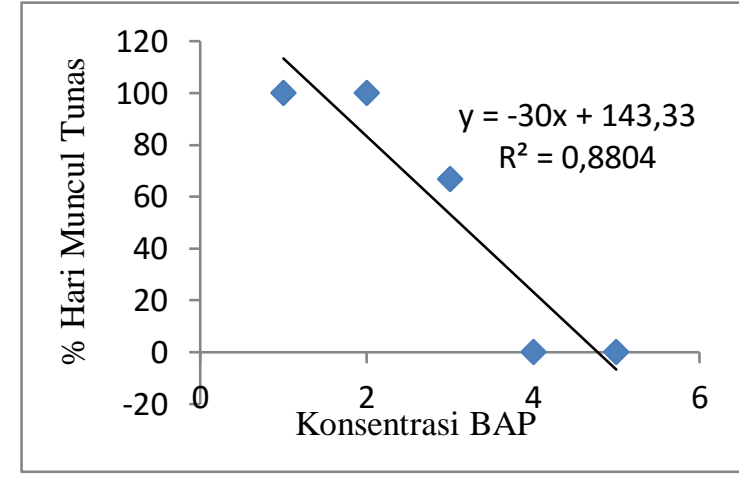

Gambar 6. Korelasi BAP Terhadap Persen Hari Munculnya Tunas pada IAA $1 \mathrm{mg} / \mathrm{L}$ (Correlation between BAP Concentration with the Percentage of Shoots in the $1 \mathrm{mg} / \mathrm{L}$ of IAA

dibandingkan dengan pemberian BAP. Koefisien determinasi konsentrasi IAA sebesar $78 \%$ sedangkan koefisien determinasi BAP sebesar $88 \%$. Hal ini 
sesuai dengan pendapat Maryani dan Zamroni (2005) yang mengatakan bahwa zat pengatur tumbuh sitokinin berperan dalam pembelahan sel dan morfogenesis, sedangkan auksin berperan dalam mengatur pertumbuhan dan pemanjangan sel.

Sitokinin adalah hormon yang memberikan pengaruh besar terhadap munculnya tunas, dan BAP adalah sitokinin yang sering digunakan untuk merangsang pembentukan tunas. Menurut Mok et al. (2002) BAP adalah sitokinin yang meningkatkan pembelahan sel dan pembesaran pada sel kultur jaringan yang mampu merangsang pertumbuhan tunas planlet. Menurut Suhenteka dan Sobir (2010) tanaman yang berbeda dapat merespon hormon dalam berbagai konsentrasi secara berbeda pula. Hal ini disebabkan oleh perbedaan hormon endogen itu sendiri. Menurut Wijayani et al. (2007) kecepatan pertumbuhan yang terjadi pada eksplan dikarenakan adanya interaksi yang tepat antara hormon endogen eksplan dengan penambahan hormon eksogen. Akibat dari interaksi itu proses fisiologi dalam eksplan berlangsung efektif, yang akhirnya mampu memacu awal pertumbuhan tunas.

\section{Tinggi Planlet}

Korelasi konsentrasi IAA terhadap tinggi planlet pada BAP $4 \mathrm{mg} / \mathrm{L}$ memiliki hubungan yang lemah, dengan koefisien determinasi sebesar
$78 \%$ (Gambar 7). Sedangkan konsentrasi BAP terhadap tinggi planlet pada IAA $0,5 \mathrm{mg} / \mathrm{L}$ memiliki hubungan yang sangat kuat, dengan koefisien determinasi sebesar $82 \%$ (Gambar 8).

Pertambahan tinggi planlet dapat dipengaruhi dengan adanya penambahan zat pengatur tumbuh, khususnya pemberian zat pengatur tumbuh berupa sitokinin (BAP). Zat pengatur tumbuh eksogen diberikan guna memberikan perimbangan terhadap hormon endogen agar mampu mempengaruhi respon fisiologis sebagai pendorong pembelahan dan perpanjangan sel (Kasutjianingsih et al. 2010). ZPT adalah senyawa organik bukan nutrisi yang dalam konsentrasi rendah dapat mendorong, tetapi jika terdapat dalam konsentrasi tinggi dapat menghambat pertumbuhan dan perkembangan tanaman (Karjadi 2002). Sitokinin pada kultur jaringan dibutuhkan untuk aktifitas pembelahan sel tumbuhan. Secara umum, pertambahan tinggi planlet ini disebabkan oleh dua proses yaitu pembelahan dan pemanjangan sel yang pada jaringan meristem, yaitu pada titik tumbuh (Bey et al. 2006). Kedua proses ini dipengaruhi oleh hormon auksin dan sitokinin. Menurut Dwiani et al. (2009) kadar sitokinin eksogen menyebabkan pembelahan sel pada jaringan meristem terus dapat ditingkatkan aktifitasnya. 


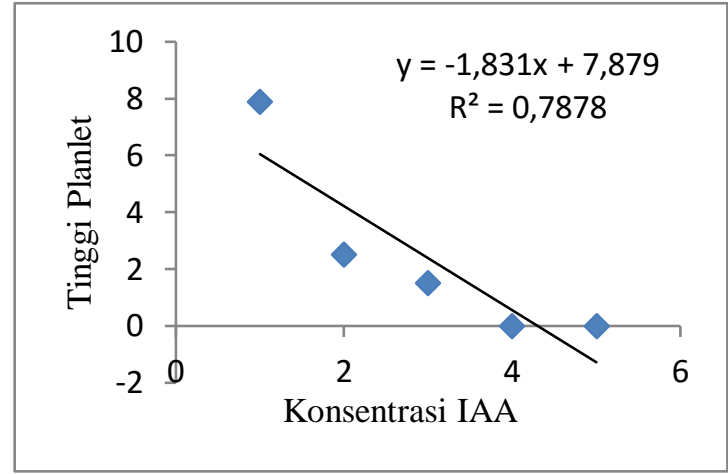

Gambar 7. Korelasi IAA Terhadap Tinggi Planlet pada BAP 4 $\mathrm{mg} / \mathrm{L} \quad$ (Correlation between IAA Concentration with the Planlet Height in the 4

\section{E. Persentase Hari Munculnya Daun}

Kecepatan pertumbuhan daun diamati selama 30 hari pengamatan

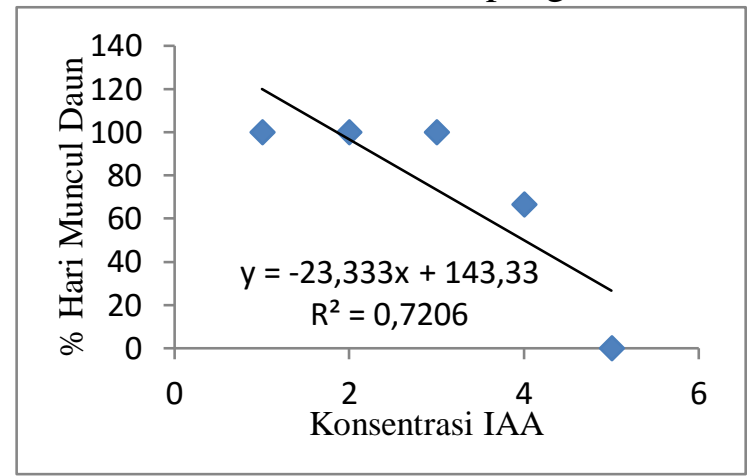

Gambar 9. Korelasi IAA Terhadap Persen Hari Munculnya Daun pada BAP $0 \mathrm{mg} / \mathrm{L}$ (Correlation between IAA Concentration with the Percentage of Days the Appearance Leafs in the 0 $m \mathrm{~m} / \mathrm{L}$ of BAP Concentration)

Pengaruh konsentrasi IAA terhadap hari munculnya daun pada konsentrasi BAP $0 \mathrm{mg} / \mathrm{L}$ lebih lemah dibandingkan dengan hubungan konsentrasi BAP terhadap hari

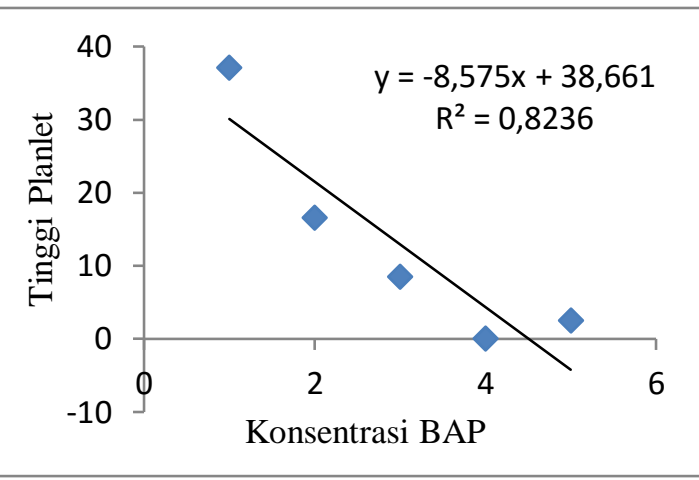

Gambar 8. Korelasi BAP Terhadap Tinggi Planlet pada IAA $0,5 \mathrm{mg} / \mathrm{L}$ (Correlation between BAP Concentration with the Planlet Height in the 0.5

sejak eksplan. Korelasi IAA dan BAP terhadap persentase hari munculnya daun tersaji pada Gambar 9 dan 10.

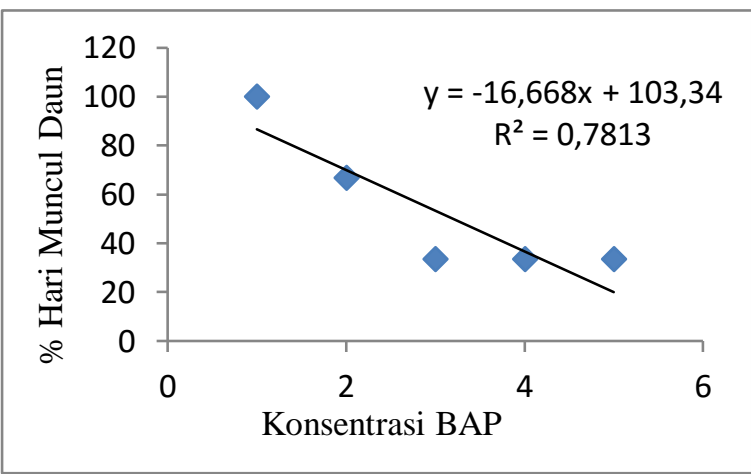

Gambar 10. Korelasi BAP Terhadap Persen Hari Munculnya Daun pada IAA $0 \mathrm{mg} / \mathrm{L}$ (Correlation between BAP Concentration with the Percentage of Days the Appearance Leafs in the 0

munculnya daun pada konsentrasi IAA 0 mg/L. Menurut Mashud (2013) pengaruh zat pengatur tumbuh eksogen dalam media in vitro ditentukan oleh kandungan zat pengatur tumbuh 
endogen (dalam jaringan tanaman) yang sama atau berbeda. Artinya pengaruh BAP eksogen dalam media tumbuh terhadap pertumbuhan planlet umumnya dan jumlah daun khususnya, ditentukan oleh kandungan BAP atau golongan sitokinin endogen lainnya. Triningsih et al. (2013) mengemukakan bahwa faktor tunggal konsentrasi BAP dalam media in vitro memberikan pengaruh yang baik terhadap kecepatan munculnya daun. Perbandingan sitokinin yang lebih besar daripada auksin pada kultur in vitro akanmenstimulasi pertumbuhan tunas dan daun, tetapi untuk konsentrasi BAP yang terlalu tinggi akan menghambat pertumbuhan daun. Menurut pendapat Yuniastuti et al. (2010) bahwa perlakuan dengan konsentrasi BAP tinggi tidak dapat membentuk daun.

\section{F. Jumlah Daun}

Daun merupakan tempat berlangsungnya proses fotosintesis, karena pada daun proses pembentukan karbohidrat terjadi.Semakin banyak daun yang muncul pada eksplan, mengindikasikan pertumbuhan eksplan lebih baik. Jumlah daun yang banyak akan menghasilkan fotosintat yang banyak pula sehingga pertumbuhan tanaman akan semakin baik (Hartati et al. 2016).

Berdasarkan hasil analisis korelasi pada Gambar 11 dan 12 bahwa pemberian konsentrasi IAA terhadap jumlah daun pada konsentrasi BAP 1 $\mathrm{mg} / \mathrm{L}$ memberikan pengaruh yang lebih lemah daripada pemberian konsentrasi BAP terhadap jumlah daun pada konsentrasi IAA $0 \mathrm{mg} / \mathrm{L}$. Korelasi konsentrasi IAA terhadap jumlah daun pada konsentrasi BAP $1 \mathrm{mg} / \mathrm{L}$ memiliki koefisien determinasi sebesar $77 \%$, sedangkan koefisien determinasi konsentrasi BAP terhadap jumlah daun pada konsentrasi IAA $0 \mathrm{mg} / \mathrm{L}$ sebesar 79\%. Hal ini diduga bahwa dalam pembentukan daun, penambahan sitokinin eksogen akan berinteraksi dengan auksin endogen yang terkandung di dalam eksplan. Ini membuktikan bahwa pertumbuhan tanaman secara in vitro dikendalikan oleh keseimbangan dan interaksi antara zat pengatur tumbuh baik yang terkandung dalam eksplan itu sendiri (endogen) maupun yang diserap dari media (eksogen). Widiastoety dan Nurmalinda (2010), dalam jaringan daun yang mengalami tekanan osmotik terdapat akumulasi karbohidrat yang merangsang akumulasi asam absisat (ABA) di dalam jaringan tanaman yang dapat menghambat pertumbuhan tanaman. Selain akumulasi ABA terjadi pula penghambatan sintesis sitokinin yang meningkatkan hambatan pertumbuhan yang diakibatkan oleh pengaruh ABA. 


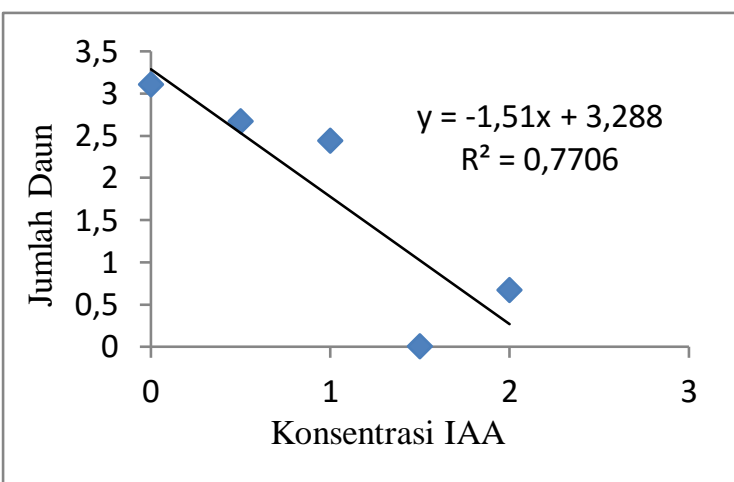

Gambar 11. Korelasi IAA Terhadap Jumlah Daun pada BAP 1 $\mathrm{mg} / \mathrm{L}$ (Correlation between IAA Concentration with the Number of Leaves in the $1 \mathrm{mg} / \mathrm{L}$ of $B A P$

\section{KESIMPULAN}

Kesimpulan yang dapat diambil dari hasil penelitian yang telah dilakukan, yaitu konsentrasi IAA memberikan korelasi yang negatif tetapi memberikan hubungan yang kuat terhadap hari munculnya akar dan panjang akar. Pemberian konsentrasi BAP juga memberikan korelasi yang negatif tetapi memberikan hubungan yang kuat terhadap hari munculnya tunas, hari munculnya daun, tinggi planlet, serta jumlah daun.

\section{SARAN}

1. Perlu adanya penelitian lanjutan mengenai kombinasi perlakuan konsentrasi IAA dan BAP terhadap pertumbuhan eksplan sengon secara kultur jaringan sehingga akan didapatkan hasil pertumbuhan yang lebih optimal.

2. Kebersihan untuk rak kultur serta ruangan penempatan botol-botol kultur yang berisi eksplan harus lebih diperhatikan lagi supaya

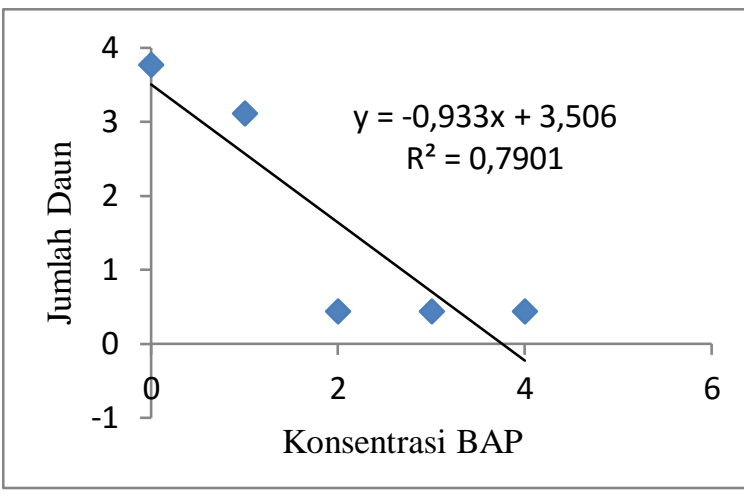

Gambar 12. Korelasi BAP Terhadap Jumlah Daun pada IAA 0 $\mathrm{mg} / \mathrm{L}$ (Correlation between BAP Concentration with the Number of Leaves in the 0 mg/L of IAA Concentration)

eksplan tidak mudah terkontaminasi jamur dan bakteri.

3. Bahan yang akan digunakan sebagai eksplan sebaiknya berasal dari bagian tanaman yang masih muda dan sehat, terutama jika menggunakan biji sebagai eksplan, harus dipilih biji yang benar-benar matang secara fisiologisnya supaya pertumbuhan yang didapatkan lebih optimal.

\section{UCAPAN TERIMA KASIH}

Terima kasih kepada KEMENRISTEKDIKTI melalui Reine Suci Wulandari, S.Hut, M.P dan Dr. Rosa Suryantini, S.Hut, M.P yang telah membantu dana penelitian ini yang berjudul "Introduksi Jamur Endofit Pada Kultur In Vitro Sengon (Paraserianthes falcataria)".

\section{DAFTAR PUSTAKA}

Agustina L. 2002. Nutrisi Tanaman. Jakarta: Rineka Cipta.

Badan Pusat Statistik (BPS). 2015. Statistik Produksi Kehutanan 
2015. Katalog BPS 5601005. Diakses dari http://www.bps.go.id[31 Juli 2015].

Bey YW, Syafii, Sutrisna. 2006. Pengaruh pemberian giberelin (GA3) dan air kelapa terhadap perkecambahan bahan biji anggrek bulan (Phalaenopsis amabilis BL) secara In Vitro. Jurnal Biogenesis. 2 : 41-46.

Damaris P. 2012. Uji daya kecambah benih sengon (Paraserianthes falcataria (L.) Nielsen) di green house. Jurnal HutanTropis. 13 : 132-138.

Dwiani RA, Purwantoro A, Indrianto, Semiarti. 2009. Peningkatan kecepatan pertumbuhan embrio anggrek vanda tricolor Lindl.Jurnal Litbang Pertanian. 2: 138-143.

Gunawan LW. 2008. Teknik Kultur Jaringan Tumbuhan. Laboratorium KulturJaringan Tumbuhan PAU Bioteknologi. Bogor : Institut Pertanian Bogor.

Hartati S, Agus B, Ongko C. 2016. Pengaruh NAA dan BAP terhadap pertumbuhan subkultur anggrek hasil persilangan Dendrobium biggibum X Dendrobium liniale. Journal of Sustainable Agriculture. 31 : 3337.

Henuhili V. 2013. Kultur Jaringan Tanaman. Yogyakarta : UNY Press.

Herawan T, Mohammad N, Sapto I, Ari I. 2015. Kultur jaringan cendana (Santalum album L.) menggunakan eksplan mata tunas. Jurnal Pemuliaan Tanaman Hutan. 9 : 177-188.

Karjadi. 2002. Perkembangan penelitian regenerasi dan transformasi tanaman kedelai. Jurnal Bul Agrobiog. 5 : 37-44.

Kasutjianingsih R, Poerwanto N, Khumaida, Efendi. 2010. Kemampuan pecah tunas dankemampuan berbiak mother plant pisang rajabulu (AAB) dan pisang Tanduk (AAB) dalam medium inisiasi in vitro. Jurnal Agriplus. 20 : 9-17.

Mashud N. 2013. Efek zat pengatur tumbuh BAP terhadap pertumbuhan planlet kelapa genjah kopyor secara in vitro. Jurnal Hutan Tanaman. 7 : 8287.

Maryani Y, Zamroni. 2005. Penggandaan tunas anggrek melalui kultur jaringan.Jurnal Ilmu Pertanian. 12 : 51 - 55.

Mok MC, Martin RC, Daniel WS. 2002. Cytokinins : biosynthesis metabolism and perception in vitro cell dev. Biologyc. Journal Plant. 36 : 102-107.

Pucchooa dan Sookum, 2000. Induced Mutation and In vitro Culture of Anthurium andraeanum.https://www.researc hgate.net/publication/307778680 _In_vitro_culture_of_Anthurium _andraeanum [17 Februari 2019].

Raharja PC. 2007. Teknik Perbanyakan Tanaman secara Modern. Jakarta: Penebar Swadaya.

Rukmana R. 2009.Kultur Jaringan Tanaman. Malang: UMM Press. 
Santoso U, Nursandi F. 2004. Kultur Jaringan Tanaman. Malang: UMM Press.

Siska DM, Imam M, Zulfarina. 2013. Pengaruh Pemberian Hormon IAA dan BAP Terhadap Pertumbuhan Tunas Anggrek (Dendrobium phalaenopsis Fitzg) secara In Vitro. Riau : Universitas Riau.

Suhenteka, Sobir F. 2010. Peranan zat pengatur tumbuh dalam perbanyakan tanaman melalui kultur jaringan. Jurnal Agro Biogen. 7 : 63-68.

Sulistiani E, Samsul AY. 2015. Produksi Bibit Tanaman Dengan Menggunakan Teknik Kultur Jaringan. Bogor: SEAMEO BIOTROP.

Triningsih A, Luthfi M, Siregar, Putri LA. 2013. Pertumbuhan eksplan puar tenangau (Elletariopsis $s p$ ) secara in vitro. Jurnal Online Agroteknologi. 1 : 276-285.

Widiastoety D, Nurmalinda. 2010. Pengaruh suplemen nonsintetik terhadap pertumbuhan planlet anggrek vanda. Jurnal Hortikultura. 20 : 60-66.

Wijayani, Yuanita, Mudyantini W. 2007. Pertumbuhan tunas dan struktur anatomi protocorm like body

Grammatophyllumscriptum anggrek dengan pemberian kinetin dan NAA. Jurnal Bioteknologi. 4 : 33-40.

Yuniastuti E, Praswanto, Ika Harminingsih. 2010. Pengaruh konsentrasi BAP terhadap multiplikasi tunas anthurium (Anthurium andraeanum Linden) pada beberapa media dasar secara in vitro. Jurnal Caraka Tani XXV. 1 : 1-6. 